\title{
Slovacikálne tlače 16. storočia v Lyceálnej knižnici v Kežmarku Mária Pitáková
}

\author{
PITÁKOVÁ, M.: The 16th Century Slovakia-related Prints in Kežmarok \\ Lyceum Library \\ SLOVENSKÁ LITERATÚRA 68, 2021, No. 1, p. 63-76 \\ DOI: https://doi.org/10.31577/slovlit.2021.68.1.5 \\ ORCID ID: 0000-0001-9695-8042
}

\begin{abstract}
Key words: historical libraries in
Slovakia, Kežmarok lyceum library, Slovakia-related prints, 16 th century, history of book culture, Bardejov
\end{abstract}

Book printing in Slovakia did not start to noticably flourish until the 16th century. The historical lyceum library in Kežmarok maintains Slovakia-related works from that period of time that were produced mainly by two printing workshops in Bardejov. They are mostly theological prints the contents of which deal with worshipping of church paintings, which many priests wanted to have removed. The Slovak nature of the sources is, besides the place of publication (the territory of present-day Slovakia), assessed according to other three criteria, i.e. author, content and language. However, the four points of view mentioned above often overlap. The largest part of Slovakia-related prints in Kežmarok lyceum library is made up of documents linked to Slovakia in terms of content. They are various monographs, occasional poems, speeches, sermons et cetera. On the contrary, the smallest group is formed by documents related to Slovak language, as German language books dominate over those written in Latin or Hungarian, which is only natural because the library was located in then German environment. Slovak books appeared there sporadically, most of the time for the purpose of ministry among the Slovak population. The copies preserved to date are also interesting with regard to their owners: the books were donated to the library by professors and students as well as by many notable aristocratic families.

Klúčové slová: historické knižnice na Slovensku, Lyceálna knižnica v Kežmarku, slovacikálne tlače, 16. storočie, dejiny knižnej kultúry, Bardejov 

kultúrnej, literárnej a vedeckej minulosti. Jednou z nich je aj Lyceálna knižnica v Kežmarku, ktorej katalóg obsahuje približne štyritisícpätsto záznamov o knihách a drobných tlačiach. Táto knižnica je bohatá na diela náboženských reformátorov, najmä nemeckých a švajčiarskych. Prinášali ich so sebou študenti z Kežmarku a z regiónu Spiša, ktorí študovali na nemeckých univerzitách, kežmarskí obchodníci zo svojich ciest do Nemecka a tiež samotní učitelia. Niektoré knihy sa do knižnice dostali ako dary významných činitel'ov reformácie na Slovensku, ked'že napr. Leonard Stöckel a Ján Sommer, učitelia kežmarskej školy, boli osobnými priatel'mi Philippa Melanchthona. Týmto spôsobom mohli mat' kežmarská škola a jej knižnica kontakty s dobovými európskymi filozofickými a umeleckými prúdmi. Vel'ký vplyv na knižnicu mal aj boj reformačnej ortodoxie s tzv. kryptokalvinistami.

Slovenský charakter prameňov vo fonde Lyceálnej knižnice v Kežmarku je posudzovaný na základe štyroch kritérií, a to autora, miesta vydania (územie súčasného Slovenska), ${ }^{1}$ obsahu a jazyka, pričom jednotlivé hl'adiská sa prekrývajú. Najväčšiu čast' slovacikálnych tlačí knižnice tvoria slovaciká z obsahového hladiska. Sú to rôzne monografické práce, príležitostné básne, prejavy, kázne a pod. Vzhl'adom na to, že knihy vydané v slovenskom jazyku sa do knižnice dostávali iba sporadicky, jazykové slovaciká tvoria najmenšiu skupinu.

Provenienčný register kníh je vel'mi široký. Najčastejšími majitel'mi boli napr. Theodor Jóny $(1817-1883),{ }^{2}$ Martin Schwartner (Pitáková 2018), rod Podkonický, Pongrác či Cornides. Niekol'ko kníh bolo vo vlastníctve bratov Genersichovcov, profesorov kežmarského lýcea Františka Nadlera (1807 - 1831) a Huga Stenczela (1808 - 1883). Viacero slovacík sa zachovalo aj vo fonde tlačí zo 16. storočia, ktoré sú zaujímavé nielen svojou skladbou, ale i tým, že niektoré z nich patrili k prvým knihám vznikajúcej školskej knižnice.

\section{Obsahové slovaciká}

Za autora prvého obšírnejšieho opisu Slovenska môžeme pokladat' talianskeho humanistu Antonia Bonfiniho (1427 - 1503) pôsobiaceho na dvore Mateja Korvína (Kuzmík 1976:115). Na diele Rervm Vngaricarvm Decades Qvatvor, ktoré pozostáva zo 45 kníh $^{3}$ a prvý raz vyšlo tlačou v roku 1568, pracoval zhruba desat' rokov (Bonfini 1568). Aj napriek mnohým nepresnostiam pri zemepisných údajoch sa v ňom nachádzajú dôležité informácie o Uhorsku, ${ }^{4}$ takže patrí medzi

1 V kežmarskom lýceu sa nachádzajú tlače z miest Banská Bystrica, Bardejov, Bratislava, Kežmarok, Levoča, Prešov, Trnava, Žilina. Najstaršie tlače sú z Bardejova.

2 Knižnica Theodora Jónyho bola výsledkom dlhoročnej zberatel'skej činnosti a bibliofilskej záluby jej majitela, ktorý v nej zhromaždil mnoho raritných a vzácnych tlačí a rukopisov (Agnet 1983).

3 Desat' kníh tvorí jednu dekádu, takže celé dielo má štyri kompletné dekády a jednu polovičnú dekádu.

4 Hoci Bonfini nesprávne určil polohu stolíc Liptovskej, Oravskej a Turčianskej v susedstve Moravy, jeho dielo obsahuje pomerne rozsiahly a dost' presný opis Slovenska. Dielo vzniklo ako prvý pokus o kritické spracovanie uhorských dejín a obsahuje aj opis prostredia, v ktorom prebiehali dejinné udalosti. Prvý raz sa čitatel'stretáva so Slovenskom pri opise strednej a východnej Európy, neskôr pri opise súdobého obrazu krajiny. Opis Žitného ostrova sa stal základom pre všetky d'alšie opisy tejto oblasti vo vlastivedných prácach 16. a 17. storočia. Významnejší je opis v druhej časti prvej knihy z prvej dekády. Môžeme ho považovat' za prvú a najstaršiu ucelenú charakteristiku Slovenska. Najskôr stručne opisuje hranice Uhorska, potom uvádza spoločenské rozvrstvenie obyvatel'stva. Nasleduje opis Uhorska podla jednotlivých komitátov. Historická čast' obsahuje vel'a materiálu k presnému vymedzeniu obsahu názvu Horná zem (Musil 1977: 44-45). 
prvoradé pramene uhorských stredovekých dejín. Tie v knihe začínajú dejinami

Húnov a končia rokom 1495 .

Bonfini využíval pri písaní svojho spisu rozsiahlu zbierku rukopisných i tlačených kníh nachádzajúcich sa na Budínskom hrade. Jeho hlavným východiskovým prameňom pri spracovaní uhorských dejín bola Chronica Hungarorum z roku 1499 od kronikára Jána Turóciho (1435-1489), z ktorej prebral aj opis mad'arských bojov proti vladárovi severovýchodnej Panónie Svätoplukovi II. (Kuzmík 1983). Ako d'alšie pramene používal Chronicon Budense (1473) a Chronicon Vindobonense (1370). Vd'aka podpore členov panovníckeho dvora mu bol sprístupnený i štátny archív. Čerpal však aj z informácií, ktoré mu sprostredkovali jeho súčasníci, napr. Ján Bornemisa, vtedajší král'ovský podpokladník a neskôr významný vel'mož, Peter More, uhorský diplomat král'a Mateja v Osmanskej ríši, Antonius di Salona, opát benediktínskeho kláštora v Siniobe. Využívanie viacerých informačných zdrojov však u neho viedlo ku skreslenej interpretácii niektorých udalostí a k početným dátumovým a faktografickým chybám. Bonfini totiž pramene len prebral, neraz aj vtedy, ked' si protirečili.

Exemplár z roku 1568 uložený v kežmarskej Lyceálnej knižnici má na začiatku knihy poškodené strany a je venovaný turčianskemu županovi a palatínskemu miestodržitel'ovi Františkovi Révaiovi (1489 - 1553) od lekára a evanjelického kňaza Martina Brennera (1541 - 1581).

Druhá práca Antonia Bonfiniho vo fonde kežmarskej Lyceálnej knižnice je Symposion, spis z roku 1572 vydaný v Bazileji (Bonfini 1572). Ide o žáner literárneho symposia, ktorý podl'a antického vzoru oživili v 15. storočí talianski humanisti. Hlavnou témou Bonfiniho spisu je problematika manželstva, intímneho života, celibátu a s nimi spojené krestanské cnosti. Zachytáva učené debaty medzi královským párom - král'om Matejom Korvínom a jeho manželkou Beatrix Aragónskou - a niekol'kými d'alšími urodzenými účastníkmi fiktívneho trojdňového symposia, humanistickými vzdelancami a reprezentantmi kléru. Ciel'om diskusie bolo hl'adanie odpovede na otázku, či je väčšou cnost'ou život v panenstve alebo život v manželskom zväzku riadenom krestáanskými hodnotami.

Bonfini venoval svoje Symposion král'ovnej Beatrix Aragónskej, no hlavným adresátom oboch jeho diel bol sám král'. V Symposione zobrazil idealizovaný obraz král'ovského manželstva a v jeho rámci obraz dokonalej manželky, silnej ženy pevných hodnôt a krestanských cností. V širšom kontexte však jeho dielo vzniklo v súlade s politickými očakávaniami neapolského dvora (Buzássyová 2018). Katolícka cirkev ho však krátko po vydaní zaradila medzi zakázané knihy.

Symposion uložené v Lyceálnej knižnici v Kežmarku obsahuje okrem predslovu autora aj venovanie od Johanna Leunclavia (1533 - 1594), nemeckého historika a orientalistu, odborníka na tureckú históriu, Jánovi Sambucovi, polyhistorovi, s menom ktorého sa spája viacero diel uložených v kežmarskom lýceu.

Vo fonde knižnice je tiež významné dielo Tripartitvm Opvs Ivris Consvetvdinarii Incliti Regni Hvngariæ Štefana Verböciho (1458 - 1541), ktorý pracoval ako stoličný úradník v Ugočskej stolici, neskôr sa stal krajinským hodnostárom (Verböci 1581). Tripartitum zostavil z poverenia uhorského snemu a král'a Ladislava II., ktorému ho aj venoval. V ňom prvý raz písomne zachytil vtedajšie uhorské zvykové právo s tendenciou upevnit' zákonom vedúce postavenie celej šlachty. Podla Tripartita všetci obyvatelia Uhorského král'ovstva (vrátane obyvatel'ov výsadných 
miest) okrem šlachty, predstavitel'ov cirkvi a obyvatel'ov slobodných král'ovských miest patrili k poddanskému stavu. Dielo tvorí prológ a tri knihy (časti), celé je rozdelené na 272 článkov (titulov). ${ }^{5}$ Je napísané súvekou barbarskou latinčinou, v ktorej sa vyskytuje množstvo výrazov slovenského a mad'arského pôvodu a tiež z iných jazykov (Luby 2002: 91). Verböci často hovorí v prvej osobe. Požadoval napr. očistenie král'ovského dvora od cudzincov a postihovanie luteránov smrtou a stratou celého majetku. Kritizoval menovanie cudzincov do najvyšších uhorských štátnych úradov. V roku 1525 dokonca otvorene žiadal pozbavit' úradu všetkých Židov a od panovníka očakával, že v budúcnosti bude mat' na svojom dvore len radcov uhorského pôvodu. Exemplár nachádzajúci sa v kežmarskom lýceu bol vydaný v roku 1581 vo Viedni a je rozšírený o vecný register.

Nemecký historik Johann Pistorius (1546-1608) priniesol vo svojom diele Polonicæ Historiæ Corpvs z roku 1582 množstvo informácií aj o Slovensku, trinástich spišských mestách, ale najmä o požiari v Bratislave v apríli 1515 (Pistorius 1582). ${ }^{6}$

Dejiny územia Slovenska spomína i slovinský diplomat Sigmund von Herberstein (1486 - 1566), ${ }^{7}$ ktorý sa preslávil napísaním obsiahlej a tematicky mimoriadne širokej práce o Rusku Rerum Moscoviticarum commentarii (1549). V diele pojednávajúcom o geografických pomeroch ruského štátu, politike, histórii, náboženských pomeroch, spôsobe života obyvatel'ov a mravoch ruskej spoločnosti na začiatku 16. storočia poskytol okrem iného aj zaujímavé informácie o baníctve na strednom Slovensku, ktoré získal na svojich diplomatických cestách (Herberstein 1551). Kniha vzbudila pozornost' nielen v západoeurópskych krajinách, ale takisto v Rusku a stala sa dôležitým dobovým prameňom pre poznanie ruských dejín. ${ }^{8}$

K slovacikám, ktoré sa zachovali vo fonde 16. storočia v Kežmarku, možno zaradit' aj dielo nemeckého humanistu Petra Apiana (1495-1552) Cosmographia (Apian 1574). Autor, ktorý bol astronómom, si založil v bavorskom meste Ingolstadt vlastnú tlačiareň, známu vydávaním mimoriadne kvalitných geografických a kartografických diel (Pitáková 2016). Dielo bolo prvý raz vydané v roku $1524^{9}$ a zaradilo sa medzi najpopulárnejšie vedecké práce tých čias, pretože prinášalo poučenie o astronómii, kartografii, zemepise, navigácii a tvorbe prístrojov. Bola to jedna z prvých kníh v Európe, ktorá pojednávala už aj o severnej Amerike. Apian v nej rozoberal mnoho tém, vrátane klimatických pásiem, použitia rovnobežiek a poludníkov, stanovenia zemepisnej šírky a dížky, mapových projekcií a pod. Jedným z dôvodov, prečo si dielo získalo vel'kú popularitu, bolo to, že obsahovalo pohyblivé papierové zariadenia, tzv. volvelles, ktoré umožňovali riešit praktické matematické úlohy. Pomocou týchto zariadení si čitatelia mohli nájst' pozíciu Slnka, Mesiaca alebo vypočítat' zemepisnú šírku pomocou výšky Slnka nad obzorom. V diele je zahrnutých pät' takýchto dômyselných zariadení a mnoho d'alších zaujímavých ilustrácií a grafov. Okrem mapy sveta sa v knihe nachádza aj malá mapa

5 Prológ má 16 článkov (titulov), prvá kniha 134, druhá 84, tretia 36.

6 K téme požiaru v Bratislave v roku 1515 bližšie Frimmová 2001; Frimmová 2015.

7 S. von Herberstein uskutočnil v rokoch 1515 - 1553 približne šest'desiatdevät' ciest po Európe aj Turecku (Picková 2005).

8 Dielo bolo niekol'kokrát vydané ešte za Herbersteinovho života. Prvýkrát v roku 1549 vo Viedni, vzápätí na to v roku 1550 v Benátkach, niekol'kokrát v Bazileji, v roku 1557 znovu vo Viedni a v Antverpách, v roku 1560 vo Frankfurte nad Mohanom a v roku 1567 v nemeckom preklade v Prahe.

9 V kežmarskom lýceu sa zachovalo dielo, ktoré bolo vydané v roku 1574. 
Grécka. Jeden volvelles je konštruovaný na mape severnej pologule. Sú tu aj súradnice zemepisných európskych miest, medzi nimi i Košíc a Bratislavy. Celkovo je zaznamenaných tridsat'dva vydaní tohto diela v latinčine, osem v holandčine, pät' vo francúzštine a dve v španielčine. Zaujímavostou je, že kniha je vyobrazená na slávnom obraze Vyslanci nemeckého umelca a grafika Hansa Holbeina mladšieho. Exemplár na obraze je otvorený na tretej kapitole a ôsmej časti na strane 258 . Diela Petra Apiana sú bohato zdobené drevorytmi, ktorých autormi boli prevažne Michael Ostendorfer a Hans Brosamer.

\section{Autorské slovaciká}

Humanistický vzdelanec, lekár, básnik, autor príležitostnej latinskej poézie a alegorických obrázkov, prekladatel'gréckych a rímskych klasikov a tiež zberatel'kníh Ján Sambucus (1531-1584) (Vantuch 1975) sa usiloval presadit' sa na habsburskom dvore. Najl'ahšou cestou bolo oslovit' mladého rakúskeho arcivojvodu Maximiliána, najstaršieho syna uhorského a českého krála Ferdinanda I., neskoršieho cisára Svätej rímskej ríše. Sambucov kariérny rast a do istej miery aj jeho vztáah s budúcim cisárom je možné sledovat' na sérii dedikačných listov a Sambucovej dochovanej súkromnej korešpondencii (Lábaj 2019). Evidujeme desat'listov venovaných Maximiliánovi. $\mathrm{V}$ piatich prípadoch ide o dedikačný list pripojený k Sambucovým vlastným alebo ním pripraveným dielam, zvyšných pät' listov má súkromný či profesionálny charakter. Jeden z listov datovaný 1 . februára 1552 vo francúzskom Dole sa zachoval aj v knižnici kežmarského lýcea. Ide o dedikačný list v pripravenom vydaní Johanna Hutticha (1490 - 1544) Romanorum principum effigies (1552), v súbore vyobrazení rímskych cisárov a cisárovien z Huttichovej numizmatickej zbierky s pripojeným krátkym medailónikom (Sambucus 1552). Sambucus ho rozšíril (išlo totiž už o tretie vydanie) o d'alšie texty a oslavné básne na cisárov (od Jakoba Micylla, Gašpara Velia Ursina, Decima Magna Ausonia a Georgia Sabina). Dielo, ktoré malo Maximiliánovi sprostredkovat' múdrost' a poznatky jeho predchodcov, chcel Sambucus cisárovi venovat aj preto, aby pochopil, akú horlivost' a nádej doňho vkladá on sám. Na záver listu Sambucus žiadal Maximiliána, aby ho spolu s rodinou prijal, pretože sú vystavení osmanským výpadom.

Najdlhší dedikačný list Maximiliánovi II., datovaný 24. júna 1567 vo Viedni, ktorý sa zachoval v Lyceálnej knižnici, je súčastou azda najslávnejšieho vydania, ktoré Sambucus pripravil do tlače - je to už vyššie spomínané dielo Antonia Bonfiniho Rervm Vngaricarvm decades (1568). Sambucus $k$ Bonfiniho textu pridal ešte niekol'ko svojich aj cudzích kratších diel. Na rozdiel od predchádzajúcich dedikácií $\mathrm{v}$ tomto prípade ide o menej osobný text. Okrem Maximiliána II. je adresovaný aj biskupom, grófom, barónom, rytierom, panónskemu ludu a tiež krajanom. ${ }^{10}$ Na piatich stranách opisuje vznik vydania diela a jeho obsah; väčšiu čast' listu zaberá výklad o histórii. V závere listu Sambucus obhajuje ešte menšie diela, ktoré pripojil k vydaniu Bonfiniho: chce, aby sa posudzovali nestranne, bez nenávisti či chvály. Maximiliánovi venoval Sambucus aj predslov svojho diela Emblemata z roku 1564. Lyceálna knižnica vlastní exemplár jeho štvrtého vydania (Sambucus

10 Invictissimo potentissimoque Caesari Maximiliano II, Ungariae, Boiemiae, Dalmatiae, Croatiae, etc. Regi, Archidci Austriae, etc. Domino, Domino suo clementissimo, deinde Pontificibus, Comitibus, Baronibus, Equitibus, populoque Pannonico, etc. dominis et popularibus suis S. 
1576). Zatial' čo so študentským životom sa Sambucus rozlúčil zbierkou Poema$t a$, svoje cestovatel'ské obdobie zakončil zbierkou veršov a obrázkov Emblemata. Podobné vydania budili v tej dobe najmä v Taliansku vel'ký obdiv, a to vd'aka Alciatovi. ${ }^{11}$ Knihu pripravil Sambucov priatel', antverpský nakladatel'Christophorus Plantinus (1518/1525-1589), a bola to jedna z najkrajších kníh emblémov tých čias. Jednotlivé emblémy vznikali postupne, najprv vznikol text a nadpis, až potom obrázok. Nositel'om hlavnej myšlienky bolo heslo (motto, nadpis), ktoré predstavovalo kondenzáciu vizuálnej i slovnej zložky. Pomerne malú čast' spomedzi nadpisov tvoria priame citáty z antických alebo iných autorov, prípadne výroky pripisované konkrétnym osobám. Väčší počet tvoria nadpisy vytvorené na spôsob prísloví. Sú to príslovia jednak všeobecne známe a jednak vytvorené samotným autorom pre potreby daného emblému. Takmer každý Sambucov emblém má didaktický charakter. Inou jeho dôležitou vlastnostou bola stručnost' (Kákošová 1992). Sám Sambucus charakterizoval emblémy ako akúsi „vedu o živote“ podanú básnicky, a tým aj prítažlivo (Kákošová 2010: 58 ).

Z 223 emblémov v druhej edícii má 88 emblémov dedikáciu a 27 básní je adresovaných členom spoločnosti humanistických vzdelancov Republica literaria, kam patril i Sambucus (Almási 2009: 84). Emblemata venoval Sambucus aj svojim patrónom, ktorí ho podporovali počas jeho štúdií na prestížnych školách, významným členom viedenského dvora a nakoniec svojim príbuzným a priatelom. Ked' ich Sambucus písal, nemal vždy na mysli konkrétne venovanie. Svedčí o tom skutočnost', že v jednotlivých vydaniach venovania menil, vypúštal a pridával nové (Vantuch 1975: 107).12 Novými adresátmi boli napr. vysokí cisárski úradníci či šlachtici ako cisársky sekretár Wolfgang Haller, cirkevný a krajinský hodnostár Pavol Bornemisa, tlačiar z Bazileja Johann Oporin, editor z Antverp Christophorus Plantinus, pedagóg a reformátor Johannes Sturm a iní. Počas Sambucovho života mali Emblemata niekol'ko vydaní (1564, 1566, 1569, 1576, 1584), jedno bolo posmrtné (1589). Boli preložené do francúzštiny (1567) a holandčiny (1566).

K autorským slovacikám môžeme zaradit' aj dielo Hieronymi Savonarolæ Ferrariensis, Ordinis Prædicatorum z roku 1596 od Girolama Savonarolu (1452-1498) (Savonarola 1596). Obsahuje dedikáciu slovenského lekára, politika, filozofa a autora vedeckých spisov Jána Jessenia-Jesenského (1566-1621). V dedikácii Friedrichovi Wilhelmovi velebí Jessenius panovníkove zásluhy o rozvoj vzdelanosti, čo je obvyklý topos všetkých dedikácií. Niektoré pasáže sú však pomerne nezvyčajné. Jessenius totiž dedikáciu začína chválou „skvelého rodu Mediciovcov, ktorýs vynaložením značných prostriedkov"vyrval zo skazy mnohé rukopisy a poskytol útočisko mnohým intelektuálom z byzantskej ríše. Jessenius vyslovuje chválu na rod, ktorý Savonarola (Chlíbec - Černušák 2008) odmietal a razantne kritizoval (Nejeschleba 2012).

11 Výrazom emblém sa označuje trojdielna kombinácia textu a obrázkov, ktorá obsahuje krátky názov, dlhší popis a obrázok. Emblémy často čitatelovi oznamujú didaktické, morálne alebo vtipné posolstvo. Za zakladatel'a žánru sa považuje taliansky právnik a spisovatel'Alciati (1492 - 1550), u ktorého sa každý emblém začína na novej stránke, pozostáva z motta alebo nadpisu, obrázku pod ním a veršovaného textu. Prvá Alciatiho zbierka emblémov bola vydaná v Augsburgu v roku 1531 a neskôr sa objavila v preklade vo viac ako 150 vydaniach (Green 1872).

12 Toto konštatovanie A. Vantucha sa však nepotvrdilo, išlo len o doplnenie adresátov. 
V roku 1560, krátko po svojom príchode na Slovensko vydal Martin Ra-

kovský (1535 - 1579), pôvodom z turčianskej obce Rakovo, filozoficko-politický traktát Libellvs, De Partibvs Reipvb: Et Cavsis Mvtationvm Regnorum, Imperiorumq (Najjasnejšiemu vladárovi a pánovi, pánu Maximilánovi; Rakovský1560). Ide o veršované úvahy o rozvrstvení obyvatel'stva, príčinách štátnych prevratov a spravodlivom spoločenskom zriadení (Mišianik 1974:159). Dielo má 348 elegických distích a pozostáva $\mathrm{z}$ krátkeho úvodu, z troch nerovnako rozsiahlych a tematicky rozdielnych častí a zo stručného záveru. V prvej časti opisuje a hodnotí občanov podl'a tried, z ktorých sa skladá štát. V druhej opisuje pomery v biblickom Kafarnaume, ktorý prezentuje ako príklad najkrajšej obce. $V$ tretej časti rozvádza príčiny štátnych prevratov. Svoju filozoficko-politickú báseň venoval Rakovský najstaršiemu synovi cisára Ferdinanda Maximiliánovi, ktorý bol už niekol'ko rokov českým král'om a bol predpoklad, že sa stane aj uhorským král'om. Panovníka uist'oval o svojej oddanosti a prial mu zdravie a št́astie pri správe král'ovstva. V závere sa obrátil na Maximiliána a snažil sa získat' si jeho priazeň. $K$ dielu je ešte pripojený d'alší text s názvom Chválospev na Nádašdiho, ktorý je pozoruhodný v tej súvislosti, že žiadny uhorský básnik pred Rakovským nenapísal chválospev na domáceho politika. Oslavná báseň na Tomáša Nádašdiho (1498 - 1562), ktorý bol stoličným a krajinským hodnostárom a bol známy svojimi stykmi s humanistickými vzdelancami a podporovaním reformácie a protestantskej spisby, pozostáva z úvodu, z opísania života, zásluh a cností oslavovaného a zo stručného záveru (Okál 1979: 192-237).

\section{Slovaciká podla miesta vydania: knižná produkcia bardejovských tlačiarov}

V kežmarskej Lyceálnej knižnici je viacero diel, ktoré vydali lokálni tlačiari a ktoré majú skúmaný slovacikálny ráz aj vzhl'adom na pôvod či pôsobenie ich autorov na území dnešného Slovenska a taktiež i s ohl'adom na pertraktované témy.

Prvým významným bardejovským tlačiarom 16. storočia bol Dávid Gutgesel (1540 - 1599). ${ }^{13} \mathrm{Z}$ jeho tlačiarne vyšli popri iných tlačiach aj diela humanistu Leonarda Stöckela (1510 - 1560) (Kuzmík 1976b: 713; Hajduk 1999), u ktorého v Bardejove študoval i vyššie spomenutý Martin Rakovský. ${ }^{14}$ Stöckel ako rektor bardejovskej mestskej školy zaviedol podl'a wittenberského vzoru trojtriedny systém a zostavil pre školu zákony, ktoré kládli požiadavky nielen na žiakov, ale i na učitel'ov (Gašparovičová 2011; Škoviera 2018). Záležalo mu na tom, aby sa obnovená cirkev pridržiavala biblického učenia a neupadala do povier. Napísal viacero učebníc a niekol'ko spisov na ochranu protestantizmu. Jeho dielo Formvlae patrí k prvým textom vytlačeným na území Slovenska (Stöckel 1578). Zhrnul v ňom pravidlá pre spracovanie kázní. Kniha vydaná po smrti autora vyšla v roku 1578 v Bardejove, takisto u Dávida Gutgesela. Dielo v rozsahu 533 strán obsahuje 92 vzorov kázní. Okrem nedele a sviatkov pridal Stöckel dva výklady na Vianoce. Chýbajú kázne na Štedrý deň, starý a Nový rok a na Vel'ký piatok, z čoho vidiet',

13 D. Gutgesel bol zakladatel'om prvej bardejovskej kníhtlačiarne. Protestantsky orientovaná tlačiareň, disponujúca rozsiahlou zásobou antikvy, fraktúry, hebrejského aj gréckeho tlačového písma, fungovala až do Gutgeselovej smrti s t'ažkostami, ale napriek tomu najdlhšie zo všetkých dielní na Slovensku v 16. storočí. Vydával kalendáre, náboženskú reformačnú literatúru, učebnice a príležitostné básne (Repčák 1975). 14 Stöckel na Rakovského mimoriadne zapôsobil, čo možno odvodzovat' z toho, že Rakovský mu vo svojej neskoršej básnickej tvorbe venoval vel'kú pozornost'. 
že v tom čase v uvedené dni nebývali sväté omše. Dedikačný list je adresovaný Michalovi a Františkovi Révaiovcom, županom Turčianskej stolice. Je to azda posledný zachovaný Stöckelov list, ktorý možno pokladat' za stručný duchovný odkaz humanistu a reformátora. Podl'a dátumu venovania sa vydanie tohto diela niekedy kladie do roku 1560 a do Bardejova, no tam vtedy ešte nebola tlačiareň.

V druhom diele Leonarda Stöckela Postilla, vydanom posmrtne, ktorého exemplár má vo svojom fonde aj knižnica kežmarského lýcea (Stöckel 1596), použil citáty z diel antických spisovatel'ov, kritizoval katolícku cirkev, islam a anabaptistov. V prvej časti vypracoval kázne na texty epištol a evanjelií, v druhej na pamätné dni apoštolov. V kázňach sa zaoberal osobou Ježiša Krista (reálnou prítomnostou vo večeri Pánovej, predestináciou, cirkvou). Je tu spolu 187 kázní. Sú pomerne rozsiahle, v rozsahu pät' až šest' vel'kých strán. Kniha vyšla s podporou šl'achticov Štefana Hommonaia, Ostrožičovcov, Štefana Petröciho, Šimona Jesenského, Krištofa Kubíniho a evanjelických farárov Liptova, Turca a bojnického okolia. Syn Leonarda Stöckela knihu venoval Františkovi Révaiovi ml. a jeho synovi Gabrielovi. Lyceálnemu exempláru Postilly chýba titulný list. Na posledných dvoch stranách je príhovor Severína Škultétyho (1550-160o) čitatel'ovi. Dielo do tlače pripravili Martin Wagner (1547 - 1590), Tomáš Faber (? - 1591) a Mikuláš Erhard (? - 160o). Vydané bolo posmrtne, ako už bolo uvedené, v Bardejove Dávidom Gutgeselom v roku 1596. Rovnako ako Formvlae aj Postillu napísal Stöckel v latinčine, hoci v Bardejove sa v danom čase kázalo aj v nemčine (Grusková 2013). Medzi významné diela publikované v Bardejove tlačiarom Dávidom Gutgeselom a zachované v kežmarskej Lyceálnej knižnici patrí bezpochyby konvolút Gregora Horváta Stančiča $(1558$ - 1597) Responsionis Gregorii Horwath aliter Stansith, de Gradecz, Partim anthithesi Sebastiani Lam Calvinistæ Keismarcensis (Odpovede...; Horvát 1593). Autor pochádzal z chorvátskeho šlachtického rodu, ktorý dostal za zásluhy v boji proti Turkom v roku 1556 od Ferdinanda I. majetky na Spiši. Jeho otec Gregor Horvát založil v Strážkach školu, ktorú navštevovali prevažne šlachtickí synovia. Sám ju viedol a prednášal na nej dialektiku, etiku a rétoriku.Zasahoval do dobových teologických sporov v protestantských cirkvách, predovšetkým do zápasov okolo Formule concordiae, ktorej bol zástancom. V týchto sporoch okrem iného odmietol odstraňovanie umeleckých artefaktov z evanjelických chrámov. Tam, kde im hrozila skaza, sa usiloval o ich záchranu, preto je aj v súčasnosti považovaný za jedného z predchodcov starostlivosti o záchranu umeleckých a historických pamiatok. Patril k významných mecénom vzdelania a kultúry na východnom Slovensku (Saktorová 2007). Svojimi spismi bojoval proti kryptokalvinizmu ${ }^{15}$ a konkrétne proti jednému $\mathrm{z}$ jeho predstavitel'ov na východnom Slovensku - Šebastiánovi Lamovi (1544-1600). ${ }^{16}$ Tretia čast' Responsionis vyšla až po Stančičovej smrti v roku 1597.

15 Bol to ideový smer protestantskej teológie, ktorý chcel pod vplyvom kalvínskej reformácie odstránit' z kostolov obrazy, oltáre a organy.

16 Evanjelické synody v Levoči 1595 a v Prešove 1596 obvinili Š. Lama z kryptokalvinizmu, synoda v Sabinove v roku 1599 ho už obvinila ako falošného proroka a kalvinistu (Baráthová 2009). 
V kežmarskom lýceu sa zachoval exemplár prvej časti z roku 1592 a druhej časti z roku $1593,{ }^{17}$ oba vydané v Bardejove u Dávida Gutgesela. Význam týchto polemík bol značný. Okrem zachovania krestanskej slobody slúžili na upevnenie vierovyznania luteránov na Spiši a na kultúrno-historickú obranu cenných rezbárskych umeleckých diel v chrámoch. Spodná čast' titulného listu exemplára druhej časti z roku 1593 je poškodená. Dielo obsahuje vlepený tlačený exlibris $E x$ Bibliotheca Lycei Kesmarkiensis legato Podkonitzkyano.

Druhým spisom v Horvátovom konvolúte bolo dielo Defensio Orthodoxæ Doctrinæ Šebastiána Lama, ktorý bol po roku 1591 prívržencom kalvinizmu (Lam 1592). Pod ochranou rodiny Tököli viedol Lam vieroučné spory hlavne s učitel'mi šlachtickej rodiny Gregora Horváta v Strážkach. Mal spory s prívržencami Formule concordiae o vieroučných otázkach aj o prípustnosti obrazov v evanjelickom chráme. Sám bol za ich odstránenie. K jeho hlavným odporcom patrili Gregor Horvát, Eliáš Láni (1570 - 1618) a Albert Grawer (1575-1617). Posledný menovaný je autorom piateho spisu v konvolúte - traktátu proti kalvinizmu šíriacemu sa v Košiciach Argumenta De persona Christi, ktorý bol vytlačený v Bardejove v roku 1596 tiež v dielni Dávida Gutgesela (Grawer 1596). Dielo má na poslednej strane rukopisné poznámky k textu v latinčine. Grawer venoval traktát Aegidiovi Hunniovi, profesorovi univerzity vo Wittenbergu, a Jurajovi Jánovi Volckmarovi, profesorovi na wittenberskom lýceu. Horvátov konvolút obsahuje v Odpovediach aj jeho vlas-tný spis Posthvmvs Magnifici Et Generosi Domini (1597), vydaný takisto Dávidom Gutgeselom (Horvát 1597). Obsahuje dedikáciu Mikuláša Erharda Dalhelmia (? - 1600), rektora v Strážkach, venovanú Severínovi Škultétymu.

Koncom 16. storočia vznikla polemika o potrebe obrazov v kostole a výzdobe vôbec. Kňazi, ktorí sa prikláňali k reformovanému učeniu, obrazy a výzdobu úplne zavrhovali. Vyvijali svoju činnost' na Spiši pod ochranou grófa Šebestiána Tököliho. Jedným z nich bol Tomáš Faber, ktorý v diele Disceptatio de imaginibus odmietal uctievanie obrazov. Na jeho tvrdenia polemicky odpovedal Eliáš Láni zo Stančičovej školy v Strážkach spismi Scvtvm libertatis (Štít slobody, vydanom v Bardejove Dávidom Gutgeselom roku 1595) a Defensio Libertatis Christianæ in Vsv Imaginvm Historico (Obrana krestanskej slobody, 1599, vydanom rovnako v Bardejove, ale Jakubom Klossom). Láni, ktorý bol aktívny aj ako autor duchovných piesní a vynikal v hymnológii, riešil v týchto dielach otázku vztahu umenia a viery, pričom bránil ponechanie obrazov v chrámoch ako náboženskú slobodu. Poukazoval na úžitkovú a didaktickú funkciu výtvarnej výzdoby, a tak sa výraznou mierou zaslúžil o zachovanie významných výtvarných diel na Spiši a v Šariši. Jeho polemiky mali politický i spoločenský zmysel. Neskôr Faber napadol priamo Lániho spisom Exarmatio Scvti Laniani (Faber 1597) a ten odpovedal d'alším spisom Defensio, vydanom tiež v Bardejove. Predslov tohto diela je venovaný turčianskym županom Petrovi a Františkovi Révaiovcom a je vyjadrením autorovej vd'ačnosti za podporu.

17 Je to konvolút obsahujúci diela Posthvmvs magnifici Et Generosi Domini (1597); Admonitio Gregorius Horvath (1593); Antithesis Vbiqvitatis (1591); Orthodoxæ Doctrinæ de persona Christi (1591); Defensio Orthodoxæ Doctrinæ Šebastiána Láma (1592); Scvtvm libertatis Christiæ (1595) a Defensio Libertatis Christianæ (1599) Eliáša Lániho; Argumenta De persona Christi Alberta Grawera (1596). 
Naopak, za odstránenie všetkých obrazov a sôch z kostolov bol napr. Gašpar Pilc (1522 - 1606). Na jeho názory zareagoval Georg Creutzer (1540 - 1599), pôvodom zo starej kežmarskej rodiny, ktorý Pilcovi vyčítal, že piesne v spevníku prispôsoboval falošnému učeniu a chcel odstránit' z kostola organ. Na Creutzerovu brožúrku Warnung / Vor der Sacramentierer / Zinglianer vnd Caluinisten Lehre (Creutzer 1586) odpovedal Pilc spisom Merkzeichen vydanom v zahraničí (pravdepodobne vo Vizsoly v Mad'arsku), pretože v Bardejove by toto kryptokalvinistické dielo nevytlačili.

Z bardejovskej tlačiarne Dávida Gutgesela pochádza aj dielo Examen Thesivm $\mathrm{z}$ roku 1586, ktorého autormi sú Martin Wagner, Tomáš Faber a Severín Škultéty (Wagner 1586). Podnetom k vzniku ich spisu boli diela už spomenutého Gašpara Pilca, ktorý vo svojich prácach hlásal odklon od luteránskej ortodoxie. Uhorskí luteráni žiadali Pilca, aby odvolal svoje názory a postoje, čo však Pilc neurobil a jeho odpoved'ou boli Propositiones zhrnuté v 79 bodoch (Saktorová 2007). Bardejovská cirkev i škola poverili predstavitel'ov luteranizmu Wagnera, Fabriho a Škultétyho napísat' a vydat' spis Examen Thesivm, ktorým sa začal otvorený polemický boj reformovaných cirkví. Venovanie v diele patrí kňazom, cirkvi, podžupanovi, zemianstvu, richtárom a senátorom Šarišskej stolice a piatim slobodným mestám. ${ }^{18} \mathrm{~V}$ knihe sa nachádza vlepený tlačený exlibris Ex Bibliotheca Lycei Kesmarkiensis legato Pongraziano ${ }^{19}$ a rukopisný záznam Emerici Pongrácz.

Z Gutgeselovej tlačiarne pochádza aj pohrebná kázeň Christliche Leichpredigt z roku 1591, ktorej autorom bol Samuel Sautter. Tlač má mimoriadny význam v tom, že je to prvá nemecká báseň v Uhorsku. Je to tiež jedna zo šiestich pohrebných kázní, ktoré boli vytlačené a uverejnené v Uhorsku pred rokom 1600 (z týchto šiestich pohrebných kázní boli štyri napísané latinsky, jedna bola v mad'arčine a jedna v nemčine). Tlač sa skladá z troch častí: titulná strana, predslov a samotná kázeň (Sautter 1591). Zväzok nemá ani epicedium, ani životopis. Titulný list neobsahuje impresum, ale biblický žalm v dolnej časti titulného listu, ${ }^{20}$ ktorý bol určený ako motto, myšlienka tlače, nie ako text kázne. ${ }^{21}$ Predslov má osem strán, čo predstavuje takmer jednu tretinu celkovej tlače. Na konci predslovu je požehnanie. Samotná kázeň začína na desiatej strane po predslove. Za nadpisom sa nachádza text $\mathrm{z}$ Biblie ${ }^{22}$ a dvojstranové exordium. Na konci tretej časti je formálny životopis bez názvu. Kázeň má dve hlavné témy: smrt'a vzkriesenie. Sautter poukazuje na to, že každý musí zomriet' a nikto nemôže uniknút' smrti rovnako ako Boh, Mojžiš či proroci. Dodáva, že človek je ako pluzgier alebo vodná bublina, ktorá môže za okamih zmiznút'. Sautter dielo venoval Tobiášovi Zobnerovi, Lukášovi Feinovi, Davidovi Gerstnerovi a Michalovi Wirthovi.

18 Košice, Levoča, Bardejov, Prešov a Sabinov.

19 Členovia rodu Pongrácovcov sa vyznamenali ako vysokí vojenskí hodnostári, viacerí vyštudovali právo, stali sa z nich významní advokáti či cirkevní hodnostári. Boli medzi nimi aj maliari a literáti (Machala 2007: 58).

20 Žalm 90, 12: „A tak nás nauč rátat' naše dni, aby sme našli múdrost' srdca.“

21 V neskoršom období bolo heslo tlače, ak vôbec, iba na chrbte titulného listu.

22 Ján 5, 28-29: „Nedivte sa tomu, lebo prichádza hodina, ked'všetci v hroboch počujú jeho hlas a vyjdú: tí, čo robili dobre, budú vzkriesení pre život a tí, čo páchali zlo, budú vzkriesení na odsúdenie.“ 

(? - 1618). ${ }^{23} \mathrm{Z}$ jeho dielne sa v kežmarskom lýceu nachádza exemplár Adagiorvm Græcolatinovngaricorvm Chiliades quinque z roku 1598 od Erasma Rotterdamského (1467-1536) (Erasmus 1598). Vydavatel'om a prekladatel'om diela bol mad'arský spisovatel'a zberatel' prísloví János Baranyai Decsi (1560-1601). Autorovým zámerom bolo poskytnút pomoc pri verejných vystúpeniach. Dielo je venované Jurajovi Varkuczovi, o ktorom nie je nič známe. Úvod oslovujúci čitatel'ov má 16 strán. V diele sa nachádza aj rukopisná poznámka v mad'arčine o pobyte Juraja Rákociho v Pol'sku. Na konci je latinská báseň dlhá 20 riadkov od Jána Balogu.

Vzorom tejto zbierky bolo Erasmovo bazilejské vydanie latinských fráz a citátov z roku 1574, ktoré zachovávalo nasledovnú štruktúru jednotlivých hesiel: príslovie (v latinčine alebo v gréčtine s latinským prekladom), vysvetlenie jeho základného významu, súpis použití u antických autorov (niekedy rozbor rôznych jazykových podôb alebo rôznych interpretácií u rôznych autorov), širší význam príslovia a možnosti jeho použitia v Erasmovej súčasnosti.

Kniha, ktorú pripravil Baranyai Decsi, obsahuje asi 900 prísloví, aj staršieho pôvodu. ${ }^{24} \mathrm{~V}$ úvode je vysvetlené, ako príslovia pomáhajú porozumiet' základným disciplínam, ako sú filozofia, rétorika a sčasti dialektika. Vo svojich prejavoch ich môžu využívat' teológovia, právnici, lekári, no takisto básnici a rovnako politici. V niektorých prípadoch sa v Adagiorvm objavujú iba presné latinské ekvivalenty niektorých chýbajúcich prísloví. Ich preklady, ktoré sa v priebehu času stali bežnými prísloviami, dovtedy neboli známe ako príslovia. Grécky text je často zvýraznený pred latinským textom.

Z tlačiarenskej produkcie Jakuba Klossa je v knižnici kežmarského lýcea uložená aj latinská zbierka básní Jána Bocatia (1569-1621) Hungaridos libri poematum V. (Bocatius 1599). Zahŕňa prvý doklad o školskom výlete do Vysokých Tatier vôbec - v básni adresovanej priatel'ovi a kolegovi Adamovi Kunischovi. ${ }^{25}$ So slovenskými študentmi sa autor zoznámil počas štúdií v Sasku a Drážd'anoch. Po ukončení štúdia odišiel na územie dnešného Slovenska, kde pôsobil ako verejný činitel', pedagóg a básnik. Bocatius patril k najproduktívnejším humanistickým básnikom na Slovensku, svoje diela písal v latinčine a nemčine a uverejňoval ich najmä v zbierkach iných autorov. $V$ jeho poézii sú zastúpené takmer všetky žánre humanistickej latinskej poézie, usporiadané do celkov, ktoré tvoria jednotlivé

23 Jakub Kloss st. (tiež Klez, Kloesz, Klösz) sa narodil v dnešnom Rumunsku. Možno predpokladat', že v Bardejove krátky čas spolupracoval s Dávidom Gutgeselom, ktorého dielňu prikúpil, vyženil alebo zdedil, pretože Gutgeselova dcéra bola jeho druhou ženou (Valach 1987).

24 Stovky Decsiho prísloví sú známe a používajú sa dodnes v rovnakom znení: „Olcsó húsnak híg a leve“ (Z lacného mäsa riedka polievka), ,Jobb ma egy veréb, holnap egy túzok“ (Lepší vrabec v hrsti ako holub na streche) atd'. Iné sa vyskytujú iba v určitých oblastiach mad'arskej jazykovej komunity alebo upadli do zabudnutia. Okrem prísloví, ktoré sú uvedené iba v mad'arskom jazyku, zbierka obsahuje aj niekol'ko prísloví známych v iných jazykoch, najmä zo severu Európy (lotyština, litovčina a estónčina). Asi tridsatpät' z nich sú rozšírené európske príslovia, ako napr. „Kéz kezet mos“ (Ruka ruku umýva), „Ajándék lónak ne nézd a fogát“ (Darovanému koňovi na zuby nepozeraj). Niektoré majú ekvivalenty v slovanských jazykoch, napr. „Borsót hány a falra“ (Akoby hrach na stenu hádzal). Ďalšie príslovia sú v súčasnosti známe iba v konkrétnych oblastiach mad'arského jazyka, napr. v Rumunsku, čo znamená, že sa stali regionálnymi prísloviami, napr. „Addig hántsd a hársat, amíg hámlik“ (Odlupujte lipový strom, kým sa neodlúpi). Iné príslovia odvtedy upadli do zabudnutia: „Úgy illik, mäta a tegezbe“ (Zapadá ako palica do tuláka).

25 A. Kunisch (1562 - 1600) vlastnil bohatú knižnicu. Bol znalcom Tatier, a preto mu Bocatius napísal list, kde ho prosil o pomoc pri sprevádzaní študentov po Tatrách. List je písaný v latinských veršoch (Karšai 1967). 
74 knihy (Kákošová 2014: 67). Do úvodnej časti básnickej zbierky Hvngaridos libri pæmatum V. M. Ioannis Bocatii Poëtx Laureati Cæsarei Hungaridos Libri Pomatvm V. umiestnil Bocatius d'akovné verše Rudolfovi II. Za nimi nasledujú dedikačné prozaické listy mecénom Krištofovi Darholtzovi a Žigmundovi Forgáčovi, niekol'kým šlachticom a čitatel'ovi. Následne uvádza skupinku epigramov, ktorými priatelia oslavujú jeho básnickú tvorbu. Dielo rozdelil tematicky do piatich častí (Kerul'ová 2009). V akom náklade Hungaridos vyšli, nevieme (Žibritová 2004). Exemplár nachádzajúci sa v kežmarskom lýceu je defektný, chýba mu prvých 162 strán.

\section{Jazykové slovaciká}

Najmenšiu skupinu slovacík v Lyceálnej knižnici v Kežmarku tvoria jazykové slovaciká. V jazykovej skladbe knižnice prevládajú nemecké knihy nad latinskými a mad'arskými. Je to samozrejmé, pretože kežmarská knižnica bola v nemeckom prostredí. Slovenské knihy sa do nej dostávali sporadicky, väčšinou pre potreby pastorácie medzi miestnym slovenským obyvatel'stvom.

Celkové množstvo slovacikálnych tlačí uchovaných na území Slovenska je tažké určit'. Aj v súčasnosti ešte prebiehajú výskumné práce v jednotlivých knižniciach na ich katalógoch. $\mathrm{K}$ dispozícii je zatial' iba menšia, ale zaujímavá práca od Vojtecha Strelku Slovacikálne tlače 16. storočia v katalógoch a knižniciach na Slovensku (Strelka 2004).

\section{Pramene}

APIAN, Peter, 1574. Cosmographia Petri Apiani, Per Gemmam Frisium Apvd Lovanienses Medicvm Et Mathematicvm Insignem. Antverpiæ: apud Christophorum Plantinum, sub Circino aureo, M. D. LXXIIII. LKež 42812, prív. 1.

BOCATIUS, Ján, 1599. M. Ioannis Bocatii Poëtæ Laureati Cæsarei. Hvngaridos Libri Poematvm V. (Bartphæ): (Excudebat Iacobus Klöss). LKež 1392.

BONFINI, Antonio, 1568. Antonii Bonfinii Rervm Vngaricarvm Decades Qvatvor, Cvm Dimidia. Qvarvm Tres priores, ante annos XX, Martini Brenneri Bistriciensis industria editx, iamque diuersorum aliquot codicum manuscriptorum collatione multis in locis emendatiores: Quarta uerò Decas, cum Quinta dimidia, nunquam antea excusæ, Ioan. Sambvci Tirnauiensis, Cæs. Maiest. Historici, \& c. opera ac studio nunc demum in lucem proferuntur: Vnà cum rerum ad nostra usque tempora gestarum Appendicibus aliquot, quorum feriem uersa pagina indicabit. Accessit etiam locuples rerum et uerborum toto Opere memorabilium Index. (Basileæ): (Per Bartholomævm Franconem, et Pavlvm Q vecvm, Svmptibvs Partim Svcessorvm Oporini, Partim Sigismundi Feirabent), (Anno Domini M. D. LXVIII.). LKež 49843.

BONFINI, Antonio, 1572. Symposion Trimeron. Basileæ: ex officina Oporiniana. LKež 12194. CREUTZER, Georg, 1586. Warnung / Vor der Sacramentierer / Zinglianer vnd Caluinisten Lehre. Bartfeld: Durch Dauid Gutgesel. LKež 52326, prív. 12.

ERASMUS ROTERDAMUS, Desiderus, 1598. Adagiorvm Græcolatinovngaricorvm Chiliades quinque. Bartphæ: Excudebat Iacobus Klöß, Anno 1598. LKež 3670, prív. 1.

FABER, Thomas, 1597. Exarmatio Scvti Laniani. [B.m.]: [b.n.], Excvsa Anno M. D. XCVII. LKež 4588, prív. 5 .

GRAWER, Albert, 1596. Argumenta De persona Christi. Bartphæ: Imprimebat Dauid Gutgesel. LKež 625, prív. 5 .

HERBERSTEIN, Sigmund von, 1551. Rervm Moscouiticarum Commentarij Sigismundi Liberi Baronis in Herberstain, Neyperg, \& Guettenhag. In his Commentarijs sparsim contenta habebis Candide Lector, Rvssiæ, \& quæ nunc eius Metropolis est, Moscouiæ, breuissimam descriptionem. Basileæ: per Ioannem Oporinum, (Anno Salutis humanæ M. D. LI.). LKež 18999, prív. 2. HORVÁT, Gregor, 1593. Responsionis Gregorii Horwath aliter Stansith, de Gradecz, Partim anthithesi Sebastiani Lam Calvinistæ Keismarcensis. [Bardejov]: [David Gutgesel]. LKež 625. 
HORVÁT, Gregor, 1597. Posthvmvs Magnifici Et Generosi Domini, D. Gregorii Horvath, aliter Stansith, de Gradecz, Domini \& hæredis in Neërer, \& c. hoc est, Responsionis. Pars Tertia. Bartphæ: Dauid Gutgesel excudebat. LKež 625, prív. 6.

LAM, Šebastián, 1592. Defensio Orthodoxæ Doctrinæ. [Vizsoly]: [Bálint Mantskovit]. LKež 625, prív. 2.

LÁNI, Eliáš, 1595. Scvtvm libertatis Christix In Vsv Ceremoniarum, nominatim autem Imaginum, oppositum Disceptationi D. Thomæ Fabricii Tholnensis Ministri Patakini, de Christianorum imaginibus. Bartphæ: [David Gutgesel]. LKež 625, prív. 4.

LÁNI, Eliáš, 1599. Defensio Libertatis Christianæ in Vsv Imaginvm Historico. Bartphæ: [Jakub Klös]. LKež 625, prív. 7.

PISTORIUS, Johann, 1582. Polonicx Historiæ Corpvs: Hoc Est, Polonicarvm Rervm Latini recentiores \& ueteres scriptores, quotquot extant, uno volumine comprehensi omnes, \& in aliquot distributi Tomos. (Basileæ): (Per Sebastianvm Henricpetri), (Anno Salvtis nostræ instavratæ, M. D. XXCII.). LKež 50937.

RAKOVSKÝ, Martin, 1560. Libellvs, De Partibvs Reipvb: Et Cavsis Mvtationvm Regnorum, Imperiorum[ue]. Viennæ Avstriæ: Excvdebat Raphæl Hoffhalter. LKež 16311, prív. 3.

SAMBUCUS, Ján, 1552. Romanorvm Principvm Effigies. Argentorati: Apvd Volfium Cephaleum, Anno M. D. LII. LKež 14618.

SAMBUCUS, Ján, 1576. Emblemata Et Aliqvot Nvmmi Antiqvi Operis, Ioan. Sambvci Tirnaviensis Pannonii. Qvarta Editio. Antverpiæ: Ex officina Christophori Plantini. LKež 14473.

SAUTTER, Samuel, 1591. Christliche Leichpredigt. Bartfeld: David Gutgesel. LKež 48959, prív. 5. SAVONAROLA, Girolamo, 1596. Hieronymi Savonarolæ Ferrariensis, Ordinis Prædicatorum, vniuersæ Philosophix Epitome. Witebergæ: sumtum impendente Andrea Hoffmanno, Bibliop, M. D. XCVI. LKež 12698.

STÖCKEL, Leonard, 1578. Formvlæ Tractandarvm Sacrarum concionum. Bartphæ: (Excvdebat Dauid Guttgesel), (Anno M. D. LXXVIII. Calendis Augusti). LKež 6971.

STÖCKEL, Leonard, 1596. [Postilla, Siue Enarrationes Erotematicæ Epistolarvm Et Evangeliorvm Anniversariorvm]. [Bardejov]: [David Gutgesel]. LKež 53858.

VERBÖCI, Štefan, 1581. Tripartitvm Opvs Ivris Consvetvdinarii Incliti Regni Hvngariæ. Viennæ Avstriæ: Sumptibus verò Erhardi Hilleri, Bibliopolæ ibidem, Anno M. D. LXXXI. LKež 42353. VERBÖCI, Štefan, 2008. Tripartitum. Ed. Erik Štenpien. Žilina: Eurokodex.

WAGNER, Martin, 1586. Examen Thesivm et Regvlarvm Zvinglianarum de Cona Domini, vulgatarum per Casparem Pilcivm. Scriptum Nomine Ecclesix \& Scholx Bartpheñ: opera \& labore Martini Wagneri Pastoris Eccle: Thomæ Fabri Ludirectoris. Seurini Sculteti Lectoris Schole. Ad finem addita est breuis Methodus veræ doctrinę de Cona Domini, opposita sex perplexis capitibus, in quæ Theses distributæ sunt. Dauid Guttgesell excudebat. LKež 737.

\section{Literatúra}

AGNET, Ján, 1983. Jónyho knižnica a jeho zberatel'ská a nákupná činnost'. In Kniha 1982. Zborníkpre problémy a dejiny knižnej kultúry na Slovensku. Martin: Matica slovenská, s. 149-159.

ALMÁSI, Gábor, 2009. The Uses of Humanism: Johannes Sambucus. Leiden: Brill.

BARÁTHOVÁ, Nora, 2009. Osobnosti Kežmarku. Kežmarok: Jadro.

BODNÁROVÁ, Miloslava, 2011. Reformácia v Bardejove v 16. storočí. In Leonard Stöckel a reformácia v strednej Európe. Prešov: Vydavatel'stvo Prešovskej univerzity pre Biskupský úrad Východného dištriktu Evanjelickej cirkvi a. v. na Slovensku a Cirkevný zbor ECAV na Slovensku Bardejov, s. 187-194.

BUZÁSSYOVÁ, L'udmila, 2018. Dva král'ovské portréty v kontexte politických sporov poslednej vlády Mateja Korvína. In Ideológia v premenách času v pamiatkach gréckej a latinskej tradície. Bratislava: Univerzita Komenského, s. 150-163.

FRIMMOVÁ, Eva, 2001. Bratislavský požiar roku 1515. In Rozpravy k slovenským dejinám. Zborník príspevkov k nedožitému 75. výročiu narodenia Pavla Horvátha. Bratislava: SAP - Historický ústav SAV, s. 92-116.

FRIMMOVÁ, Eva, 2015. Rok 1515 v premenách času: na pozadí Bartoliniho diela Odeporicon. Bratislava: Post Scriptum.

GAŠPAROVIČOVÁ, Jana, 2011. Leonard Stöckel a bardejovská humanistická škola. In Leonard Stöckel a reformácia v strednej Európe. Prešov: Vydavatel'stvo Prešovskej univerzity pre Biskupský úrad Východného dištriktu Evanjelickej cirkvi a.v. na Slovensku a Cirkevný zbor ECAV na Slovensku Bardejov, s. 230-239.

GREEN, Henry, 1872. Andrea Alciati and his books of emblems: a biographical and bibliographical study. London: Truebner. 
GRUSKOVÁ, Jana, 2013. Erasmus von Rotterdam und Leonard Stöckel: zwei Modellpredigten über dieselbe Perikope. Graeco-Latina Brunensia, vol. 18, nr. 2, s. 159-174.

HAJDUK, Andrej, 1999. Leonard Stöckel. Život a dielo. Bratislava: Evanjelická bohoslovecká fakulta UK. CHLÍBEC, Jan-ČERNUŠÁK, Tomáš, 2008. Savonarola a Florencie: jeho pưsobení a estetické názory. Praha: Artefactum.

KÁKOŠOVÁ, Zuzana, 1992. Emblémy Jána Sambuca. Slovenská literatúra, roč. 39, č. 2, s. 104-119.

KÁKOŠOVÁ, Zuzana, 2010. Latinská humanistická poézia 16. storočia v kontexte slovenskej literatúry. Bratislava: Univerzita Komenského.

KÁKOŠOVÁ, Zuzana, 2014. Zo staršej slovenskej literatúry 1. Bratislava: Univerzita Komenského.

KARŠAI, František, 1967. Najstaršia báseň o Tatrách. Vysoké Tatry, roč. 6, č. 5, s. 2.

KERUL'OVÁ, Marta, 2009. Humanista Ján Bocatius a jeho dielo Hungaridos libri poematum V. In Poeta laureatus Ioannes Bocatius. Košice: Verejná knižnica Jána Bocatia, s. 45-67.

KUZMÍK, Jozef, 1976a. Slovník autorov slovenských a so slovenskými vztáami za humanizmu. Zväzok 1. A-M. Martin: Matica slovenská.

KUZMíK, Jozef, 1976b. Slovník autorov slovenských a so slovenskými vzt'ahmi za humanizmu. Zväzok 2.

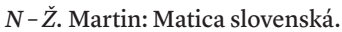

KUZMÍK, Jozef, 1983. Slovník starovekých a stredovekých autorov, prameňov a knižných skriptorov so slovenskými vzt'ahmi. Martin: Matica slovenská.

LÁBAJ, Ivan, 2019. Pohl'ad na Sambucov vztah k cisárovi Maximiliánovi II. prostredníctvom dochovanej korešpondencie. In Studia Bibliographica Posoniensia 2019. Bratislava: Univerzitná knižnica, s. 21-39.

LUBY, Štefan, 2002. Dejiny súkromného práva na Slovensku. Bratislava: Iura edition.

MACHALA, Drahoslav, 2007. Šlachtické rody. Bratislava: Perfekt.

MATUŠEVSKÁ, L'udmila, 2010. Leonard Stöckel (1510-1560). Personálna bibliografia. Bardejov: Okresná knižnica Dávida Gutgesela.

MIŠIANIK, Ján, 1974. Pohl'ady do staršej slovenskej literatúry. Bratislava: Veda.

MUSIL, František, 1977. Slovensko v dielach talianskych humanistov. Dvor Mateja Korvína a Jagelovcov. Vlastivedný časopis (Pamiatky a múzeá), roč. 26, č. 1, s. 44-45.

NEJESCHLEBA, Tomáš, 2012. Význam Jesseniova filosofického díla wittenberského období ve vztahu k saskému kurfiřtovi. In Ján Jessenius. Slováci na panovnickych dvoroch. Zborník prác z interdisciplinárnej konferencie, ktorá sa konala 13. -14. septembra 2011 v Martine. Martin:Slovenská národná knižnica, s. 32-41.

OKÁL, Miloslav, 1979. Život a dielo Martina Rakovského 1. Martin: Matica slovenská.

PICKOVÁ, Dana, 2005. První moskevská mise císařského diplomata Siegmunda von Herberstein (1517). In Staletí objevů, diplomacie a válek. Acta Universitatis Carolinae Philosophica et Historica 1-2003. Studia Historica LV. Praha: Nakladatelství Karolinum, s. 375-385.

PITÁKOVÁ, Mária, 2016. Astronóm Peter Apian a jeho dielo. Knižnica, roč. 17, č. 4, s. 62-67.

PITÁKOVÁ, Mária, 2018. Torzo knižnice Martina Schwartnera zachované v knižnici evanjelického lýcea v Kežmarku. In Kniha 2018. Zborník o problémoch a dejinách knižnej kultúry: výskum dejín knižnej kultúry na Slovensku a v stredoeurópskom priestore. Martin: Slovenská národná knižnica, s. 210-221.

REPČÁK, Jozef, 1975. Kníhtlačiareň Dávida Gutgesela v Bardejove 1577-1599. Martin: Matica slovenská. SAKTOROVÁ, Helena, 2007. Najvzácnejšie tlače z Čaplovičovej bibliografie zachované vo fonde SNK a jej majitelia. In Studia Bibliographica Posoniensia 1/2007. Bratislava: Univerzitná knižnica, s. 89-99.

STRELKA, Vojtech, 2004. Slovacikálne tlače 16. storočia v katalógoch a knižniciach na Slovensku. Trnava: Spolok sv. Vojtecha.

ŠKOVIERA, Daniel, 2018. Leonard Stöckel a reformácia. In Reformácia a jej dôsledky na Slovensku. Trnava: Filozofická fakulta Trnavskej univerzity - Bratislava: Historický ústav SAV, s. 69-78.

VALACH, Július, 1987. Staré tlačiarne a tlačiari na Slovensku. Martin: Matica slovenská.

VANTUCH, Anton, 1975. Ján Sambucus: Život a dielo renesančného učenca. Bratislava: Veda.

ŽIBRITOVÁ, Gabriela, 2004. Ján Bocatius a východoslovenskí tlačiari jeho diel. In Kniha 2003 - 2004. Zborník o problémoch a dejinách knižnej kultúry. Martin: Slovenská národná knižnica, s. 51-60.

ŽIBRITOVÁ, Gabriela, 2014. Katalógy knižníc ako prameň vo výskume dejín knižnej kultúry. Možnosti a obmedzenia. Šlachtická knižnica Ostrožičovcov z Ilavy $(1647,1677)$. In Studia Bibliographica Posoniensia 2014. Bratislava: Univerzitná knižnica, s. 26-41.

Mgr. Mária Pitáková, PhD.

Slovenská národná knižnica

Námestie Jozefa Cígera Hronského 1

03601 Martin

Slovenská republika

E-mail: maria.pitakova@snk.sk 